\title{
Krzysztof Frysztacki
}

Uniwersytet Jagielloński (Professor Emeritus)

(D) https://orcid.org/0000-0001-6832-6021

\section{O trudnościach płynących z ubóstwa i sposobach ich przezwyciężania}

Everyday Hardship. Patterns of Resilience in the Households Living in Poverty, red. nauk. Monika Gnieciak, Krzysztof Łęcki, Kazimiera Wódz, Wydawnictwo Naukowe „Śląsk”, Katowice 2020, 365 s.

\section{Uwagi wprowadzające}

Tą tematyką, a co za tym idzie tą literaturą przedmiotu, która niezmiennie zasługuje na uwagę, wzbogacając naszą wyobraźnię, wiedzę i możliwości aplikacyjne, jest obszar socjologiczno-socjalny. Oznacza to m.in. znamienny w naszym kraju, z pewnością pożyteczny oraz owocny związek między socjologią, polityką społeczną i pracą socjalną, w którego konsekwencji pojawiło się w ostatnich dziesięcioleciach szereg prac. Raz jeszcze podkreślmy znaczenie tego nurtu. W jego ramach wskażmy na konteksty, przejawy oraz sposoby reagowania na bodajże najoczywistszy, bodajże kluczowy problem społeczny, jakim jest ubóstwo; jest to splot zagadnień, którego bogactwo w naszych krajowych publikacjach zasługuje na podkreślenie. Jeśli tak, to od razu wyróżnijmy najnowsze u nas, jak piszącemu te słowa wiadomo, wymienione w nagłówku studium, będące przedmiotem niniejszego komentarza. Jest to studium, o którym można z przekonaniem rzec, że w zasługujący na podkreślenie sposób kontynuuje oraz odzwierciedla tę wskazaną linię badań. Jest bezsprzecznie wartościowe oraz godne zainteresowania i krytycznej debaty, wzmacnia to, co wiemy, oraz możliwości pozytywnego działania. 
Zanim jednak przejdziemy do właściwych temu szczegółów, w charakterze swoistego prologu przywołajmy - jako nieliczne przykłady — pewne dokumentujące ów obszar opracowania. Niejako z natury rzeczy są one mniej lub bardziej wyraziście interdyscyplinarne. Czy jednak w tych ramach podejście w szerokim sensie tego słowa socjologiczne jest uchwytne, a wręcz w poszczególnych przypadkach dominujące? Odpowiedź jest prosta i przewidywalna - naturalnie tak. O jakimś bardziej rozwiniętym poświęconym temu komentarzu w tym miejscu nie może być mowy. Ograniczmy się do uwag o charakterze sygnalnym, dotyczących pojedynczych, wybranych przypadków, z jednej strony sięgając do prac dawniejszych, a z drugiej strony wskazując przykładowo na przejawy bliższe obecnemu czasowi. W każdym razie do takich przykładów, o których można rzec, że ze względu na istotne cechy skorelowane jest z nimi recenzowane studium.

Podkreślmy na początku i przede wszystkim znaczenie Łódzkiej Szkoły Badań nad Biedą i Pomocą Społeczną. Mamy w tym nurcie do czynienia z podejmowanymi przez lata przedsięwzięciami, konsekwentnie i twórczo realizowanymi pod kierunkiem Wielisławy Warzywody-Kruszyńskiej, z ukazaniem rozlicznych i zróżnicowanych, szczegółowo dokumentowanych uwarunkowań; mamy do czynienia z pouczającym obrazem zjawisk zachodzących w mieście, które stało się znamiennym przejawem naszej rzeczywistości i naszych problemów. Przywołajmy przy tym tylko jedno studium, zarówno z wynikami badawczymi, jak i wnioskami składającymi się na „łódzki klimat” (Warzywoda-Kruszyńska, red., 1998). Przy czym cechą szczególną stało się wyróżnianie enklaw biedy i względnie całościowego splotu właściwych im czynników demograficznej, materialnej, ściślej społecznej (dez)organizacji. Przykładem kontynuacji niech będzie znowu wyraźnie uogólniająca książka Jolanty Grotowskiej-Leder (2002). Niejako w opozycji do takiego względnie syntetyzującego podejścia na wyróżnienie zasługuje również to, któremu właściwe było, takoż jest, uchwycenie bardziej zindywidualizowanej narracji, przejawiającej się na poziomie życia poszczególnych osób i rodzin. Zasygnalizujmy wymowę tych indywidualnych przypadków życiowych, wymowę autentycznych, niejednokrotnie drastycznych trudności, o jakich prosto mówili zmagający się z tymi trudnościami ludzie. Nadzwyczaj pod tym względem ważny przykład to pewne pokłosie badań o metodzie narracyjnej (Tarkowska, Warzywoda-Kruszyńska, Wódz, red., 2003). Te głównie kobiece głosy... Z kolei z nowszych — praca, której niejako konstytutywnie właściwa jest myśl i kategoria przeciwdziałania, „przeciw-problemowego” aktywizmu (Boryczko et al. 2016). Nieprzypadkowo zwrócono uwagę na tym razem współwystępowanie ujęcia socjologicznego i pedagogicznego oraz na społecznie fundamentalną zasadę społecznej solidarności. Wszystkie te punkty widzenia, powiedzmy raz jeszcze, znajdują się w dziele, któremu poświęcona jest ta recenzja.

Jeśli jednak wielość i wielorakość polskich studiów zasługuje na podkreślenie, tym bardziej, co znowu łatwo przewidywalne, możemy to powiedzieć o zagranicznej literaturze przedmiotu. W charakterze swoistego kontrapunktu odwołajmy się

264 do strony amerykańskiej; niech to znowu będzie zaledwie kilka przykładów. 
Wobec tego warto zwrócić uwagę na nurt w tamtejszej debacie i literaturze odznaczający się szczególną siłą, na nurt aksjologiczno-ideologiczny. Trudno zapewne byłoby znaleźć jakieś inne krajowe pole z równie silnymi konfrontacjami między podstawowymi stanowiskami światopoglądowymi, by ograniczyć się do wymiarów konserwatyzmu oraz progresywizmu (jako że historycznie ujmując, taki porządek chronologiczny jest zdecydowanie usprawiedliwiony). Owe zapowiedziane przykłady? Po jednej stronie ciągle najświeższej daty obszerne, nadzwyczaj we wszelakie szczegóły obfitujące dzieło, którego autorem jest powszechnie znany i wpływowy George Will (2019). Stwierdzenia, że amerykański fenomen został zapoczątkowany i był budowany na podstawie praw naturalnych, że pochodzą z nich czynniki wolności oraz jednocześnie odpowiedzialności, co oznacza poniekąd nadrzędną zasadę kształtowania własnego losu, związanych z tym wyborów, to linia przewodnia tego rozumowania. W odpowiedzi sięgnijmy do stosunkowo dawnego, bo z 1962 roku, ale cieszącego się wielkim rozgłosem i wznawianego studium Michaela Harringtona (wyk. wydanie 1997) — aż nazbyt dobitnie ukazującego amerykańskie ubóstwo jako coś znacznie więcej, niż pozornie domniemywany margines tamtejszego świata, bynajmniej nie wynikający, a w każdym razie przede wszystkim nie wynikający z ludzkich słabości, lecz płynący z błędów systemu. W tym miejscu oczywiście nie może być mowy o żadnej poświęconej temu konkluzji. Wystarczy, jeśli raz jeszcze podkreślimy znaczenie takiej debaty.

Oczywiście z tą debatą związane są nadzwyczaj bogate w rozmaite szczegóły aspekty empiryczne. W tym takie, których prezentacja ma szczególnie dobitną wymowę, co w sposób prosty (potraktujmy to oczywiście jako zaletę) przemawiałoby do wyobraźni, tak jak w ujęciu Barbary Ehrenreich (2001 — wyk. wydanie 2011). I znowu: kto (lub co) w związku z ubóstwem zasługuje w pierwszej kolejności na krytykę? Czy sami ubodzy? Wreszcie, Daniel Hatcher (2016), jako jeden z tych badaczy, którzy skupili się na dysfunkcjonalnych aspektach tamtejszego systemu socjalno-pomocowego, na wręcz wykorzystywaniu samego zjawiska ubóstwa i ludzi tym dotkniętych.

Zwróćmy przy tym uwagę, że Hatcher — w ślad za innymi — został zaliczony do kręgu określanego zgoła dumnym terminem muckrakers; ani on, ani wielu innych nie przejmowali się skłonnością do bycia przesadnie uprzejmymi. Zapewne różni to nieco polską oraz amerykańską stronę publikacyjną. My piszemy w sposób, powiedzmy tak, bardziej łagodny. Tym niemniej esencjalnie kierujemy naszą uwagę w zbliżonych kierunkach. Dobrym, wręcz bardzo dobrym tego potwierdzeniem jest Everyday Hardship. 


\section{Konfrontacja z ubóstwem w wymiarze życia codziennego}

Spoglądanie na problem ubóstwa jako na równie dominujący co dotkliwy czynnik określający codzienne losy ludzi jest naturalnie tylko jednym możliwym punktem odniesienia, co jest dobrze wiadome i co również tutaj zostało już dobitnie zasygnalizowane. Jednakże jest to punkt widzenia pod pewnymi względami szczególnie wymowny, skłaniający do myślenia. Owe w punkcie wyjścia indywidualne, rodzinne, skoncentrowane $\mathrm{w}$ gospodarstwach domowych losy przebiegają oczywiście w szerszym otoczeniu, pod wpływem właściwych mu cech charakterystycznych i zmian. Mamy więc do czynienia ze splotem czynników, które zaliczymy do ogólniejszych poziomów struktury społecznej, które odzwierciedlają względnie specyficzne, ale jednak zewnętrzne, otaczające mechanizmy regionalne i lokalne, oraz wreszcie te, które „przynależąa” danym ludziom i w decydującym zakresie określają ich unikatową egzystencję. Temu właśnie poświęcone jest studium Everyday Hardship. Patterns of Resilience in the Households Living in Poverty. Dodajmy od razu, że ma ono swoje korzenie. $Z$ jednej strony jest w znacznym stopniu pokłosiem i kontynuacją wieloletnich rozmaitych badań na Górnym Śląsku (czy też, ściślej mówiąc, również na obrzeżach Zagłębia) prowadzonych w Instytucie Socjologii Uniwersytetu Śląskiego, korzystaniem z ich rezultatów, przede wszystkim pod kierunkiem Kazimiery Wódz, z rozmaitymi wynikającymi z tego publikacjami; z drugiej strony - bezpośrednio - następstwem udziału, takoż Kazimiery Wódz i zespołów, w międzynarodowych projektach: „Social History of Poverty in Central Europe: the Polish Case”, następnie „Space, Place and the historical and contemporary articulations of regional, nationaland European identities through work and community in areas undergoing economic restructuring and regeneration”, wreszcie, traktowane jako symboliczne zakończenie, „Patterns of resilience during socioeconomic crises among households in Europe (RESCuE)" EU FP7 (zob. też doku.iab.de/forschungsbericht/2014/fbo514.pdf). Oznacza to czytelną determinację w kierunku badania i analizowania zagadnień, których znaczenie nie budzi jak sądzę żadnych wątpliwości. Oznacza jednak również pewne, powiedzmy tak, właściwe tekstowi rozproszenie źródeł i wątków.

Należy wyjaśnić, że trójka redaktorów naukowych to również jedyne osoby występujące jako autorzy tej książki, przy czym nie ma podziału na fragmenty, które są indywidualnego autorstwa poszczególnych z nich. W niektórych miejscach następuje odwołanie do wcześniejszych publikacji, przede wszystkim Wódz lub z jej udziałem. Tym niemniej ową książkę należy traktować jako wspólnie stworzoną przez ów zespół redaktorsko-autorski. Składa się ona z czterech podstawowych części. Dokonajmy ich najkrótszej możliwej prezentacji.

Pierwszą część (skądinąd wewnętrznie dość niejednorodną) w sposób konwencjonalny możemy określić mianem wprowadzenia konceptualno-teoretycznego, jednakże z przerzuceniem od razu pomostu do świata społecznego (by powtórzyć 
tę frazę) Górnego Śląska. Ten kontekst został wyznaczony swoistą rzędną rozumowania, której biegunami stały się socjologia miasta w połączeniu z socjologią życia codziennego oraz podejście antropologizujące, co naturalnie umieszcza tę pracę w ramach szeroko rozumianego paradygmatu jakościowego (zasygnalizujmy, że w całej książce nie ma ani jednego dotyczącego zebranych materiałów wskaźnika ilościowego). Doskonale wiadomo, że źródła takiego rozumowania i badawczego postępowania są rozległe i zróżnicowane, ale powtórzmy, że już na samym początku wskazane są odwołania do najstarszej pod tym względem tradycji humanistycznej, a w ślad za tym do symbolicznego interakcjonizmu czy fenomenologii — połączonymi jednak z metodologicznymi aspektami o wymowie pozytywistycznej. Od razu też został położony nacisk w socjologii życia codziennego na $\dot{z} y c i e$ w jego zasadniczych manifestacjach, przejawach komunikacji, decyzjach wiodących do rutynowych działań, w argumentach, używanych w wyjaśnianiu motywów swego postępowania (s. 16). Chodzi o analizę społecznych realiów z punktu widzenia działających podmiotów, aktywnych jednostek, ich perspektywy poznawczej, mentalności, wzorów językowych. Rzecz zaś dzieje się w konkretnych warunkach, w których ci ludzie żyją, w ich codziennych miejscach przede wszystkim w charakterystycznych górnośląskich robotniczych domach. Tak dochodzi do przeniesienia owych właściwości życiowych do ogólniejszego wymiaru regionalnego oraz do właściwego mu wymiaru transformacyjnej zmiany. Przywołując raz jeszcze termin świat społeczny, wskażmy, że ta specyficzna postać górnośląskich miejsc zamieszkania i życia, a w rezultacie tego regionu, jest czynnikiem samym w sobie, jest swoistą scenografią indywidualnego i rodzinnego losu. Zasygnalizujmy też występowanie długiego szeregu korespondujących autorów, łącznie z tymi, którzy należą do powszechnie uznawanych współtwórców historii myśli socjologiczno-antropologicznej. Kierując się trochę osobistymi upodobaniami, z przyjemnością zareagowałem na obecność w tymże wachlarzu Herberta Gansa, nieco już zapoznanego, a niezmiennie godnego przywołania. Jeśli tak, to natychmiast pojawia się łatwo rozpoznawalna kontynuacja, jako że empiryczne zainteresowanie zespołu autorskiego było zwrócone w kierunku osiedla Ksawera w Będzinie (w Województwie Śląskim, by uniknąć jakiegokolwiek nieporozumienia), splecionego pod wieloma względami z sąsiadującą kopalnią węgla kamiennego. Unikając przesadnych szczegółów, zaznaczmy, że przez wiele lat, aż do końca funkcjonowania w latach 90., nosiła najpierw miano „Paryż”, następnie „Zawadzki”, wreszcie znowu „Paryż”. Polityczno-ideologiczny kontekst tych zmian nie wymaga zapewne dalszego objaśnienia. Warto przy tym dodać, że owe zmiany, pochodzące z makropoziomu, nie pozostawały bez wpływu na lokalne wzory indywidualnej identyfikacji, zbiorowej tożsamości, zakorzenionej i utrzymywanej (również po zamknięciu kopalni) pamięci dotyczącej doświadczanego oraz, ,życiowo” wykorzystywanego miejsca. Co za tym idzie, takiego miejsca, w którym dzieją się zjawiska problemowe, w którym oczywiście dochodzi do doświadczania i codziennego przeżywania ubóstwa. Sporo smutnych odczuć po upadku tak wysoko cenionej i szanowanej (przynajmniej w odczuciu tych ludzi) pracy górniczej pozwala lepiej pojąć głosy o wymowie pesymistycznej w odniesieniu do ścisłej współczesności. 
Tytuł części drugiej: Stare i nowe ubóstwo na Górnym Ślasku mówi sam za siebie. Jeśli ogólniejszym przywołanym kontekstem jest przede wszystkim koncepcja podklasy, to wcześniej zapowiedziana perspektywa górnośląska tamtejszych enklaw ubóstwa staje się już dobitnie, wręcz kategorycznie podkreślonym desygnatem. Trzeba jednak rzec, że ów podział na stare i nowe nie został jednoznacznie i wystarczająco precyzyjnie przeprowadzony, skłaniając raczej do intuicyjnej refleksji. Linią graniczną stały się nadzwyczaj dynamiczne - i dramatyczne lata 90. (zob. s. 85-88). Z jednej strony chodzi zapewne o te względnie utrwalone przejawy, które miały korzenie bardziej historyczne, z powojennymi losami niektórych górnoślązaków na czele. Również z tradycyjnymi społeczno-kulturowymi wymiarami owego śląskiego życia, z położeniem nacisku na ograniczoną edukację, ukierunkowaną na pracę w przemyśle, co jak się okazuje może mieć swoje nieoczekiwane, sprzeczne z wcześniejszymi zdroworozsądkowymi założeniami ograniczenia. I właśnie z drugiej strony konsekwencje szokującej wręcz z punktu widzenia tych, którzy tam żyli i pracowali, dezindustrializacji (w szczególności w sektorze górnictwa), gwałtowny zanik tego, co składało się na traktowaną jako oczywista podstawę egzystencji, wywoływały wiele trudności, które swym nieoczekiwaniem i niezwykłością zasługiwały na miano czegoś zadziwiająco nowego, groźnego. W celu konkretyzacji w tym miejscu pojawiają się też silnie wyartykułowane studia rodzinnych przypadków, z rozlicznymi szczegółami, niejako w charakterze wprowadzenia do późniejszych materiałów, będących pokłosiem wywiadów przeprowadzonych w tych mikrośrodowiskach.

Wniosek płynący z owego oglądu życia rodzinnego jest nieco nieoczekiwany, ale zgoła kluczowy z punktu widzenia tego, co stanowi część następną: mamy do czynienia $\mathrm{z}$ ujednolicającym podobieństwem sytuacji, a jednak nie. W istocie pojawiają się zróżnicowane czynniki strukturalne, aksjologiczno-kulturowe, psychologiczne, skłaniające do analizy mającej na celu uchwycenie tej różnorodności i poszukiwania adekwatnych mechanizmów wsparcia.

To zaś przenosi czytelnika do trzeciej i o chronologicznie najnowszych korzeniach interpretacji, dotyczącej, ogólnie mówiąc, prób i sposobów przeciwstawiania się problemowi ubóstwa. Znowu powtórzmy, że zapewne decydującym czynnikiem nadającym tym badaniom taką, a nie inną postać był fakt udziału w wymienionym już międzynarodowym programie RESCuE. Znowu biograficzne i narracyjne wywiady miały prowadzić (z udanymi rezultatami) do wiadomości o codziennych aktywnościach. Bezpośrednio korzystając z przedstawionych tam głównych celów i założeń (s. 106-107), powiedzmy, że chodziło o ujawnienie zróżnicowanych wzorów kulturowych układów, zwyczajów, przejawów wiedzy i praktyki powiązanych z przeciwdziałaniem kryzysowi i ubóstwu; o analizę występujących wymiarów pasywnej oraz aktywnej ekspresji i partycypacji; także o analizę (kulturowych) zasobów rozwijanych z zamiarem wykorzystania w owym przeciwdziałaniu. $\mathrm{Na}$ swoistą linię organizującą te poszukiwania składały się w szczególności takie zarówno ukryte, jak i zewnętrznie manifestowane wartości i normy, które swym wpływem strukturyzują codzienne indywidualne i grupowe działania. Zaś w toku 268 przeprowadzanych wywiadów na czoło ze strony je prowadzących wysuwane były 
takie typy zasobów jak symboliczne (przykładowo życiowe priorytety), społeczne (przykładowo zaufanie), kulturowe (kwalifikacje i wiedza), społeczno-ekonomiczne (wzory konsumpcji). Co za tym idzie, a co było przewidywalne, jak również co należy uznać za trafne, ta konceptualizacja i ta analiza wyników skupione były na kategoriach poszczególnych kapitałów. Konkludując, zespół autorski położył nacisk nie tylko na realność samego ubóstwa i korespondujących trudności, co skądinąd oczywiste, ale też skoncentrował się na znaczeniu bezpośrednio otaczających społeczności lokalnych, na uchwytnych w nich przejawach zarówno integracji, jak i dezintegracji, na stosunkach wewnątrzrodzinnych, na odgrywanych w ramach tych stosunków rolach.

Wreszcie część czwarta — z pewnego względu najbardziej specyficzna i skłaniająca do refleksji. Na stu kilkudziesięciu stronach przedstawiono materiały terenowe, obszerną prezentację treści szeregu przeprowadzonych i zasygnalizowanych już wywiadów, a w tym przede wszystkim wyjątkowo rozbudowanych i pogłębionych wywiadów z Rodziną A oraz Rodziną B, z szeregiem należących do nich osób. Jest to materiał wyjątkowo intrygujący, wypełniony wiedzą o ludzkich sprawach, nadzwyczaj bogaty w to wszystko, co składa się na prozaiczne, niejednokrotnie pozornie drobne, a jednocześnie kluczowe w swym znaczeniu przejawy życia. Warto to czytać. Zaryzykujmy jednak powtórzenie jednego drobniutkiego fragmentu, ukazującego wewnętrzną solidarność w prostej — jeśli można sobie pozwolić na takie nieco ryzykowne określenie — rodzinie:

Who is the head in your family? You know, me and my husband, this is equal. If he earns any extra money, when he goes to paint somebody's flat, he always brings the money for the household. Because she [the youngest daughter] when the dad comes, he comes to see her. Even does not want the chocolate, but what's in it. So it is equal, as he brings the money, salaries, he gives them to me. In important family issues you both decide or somebody has the decisive vote? We rather both decide. Whether it is something at home, or refurbishment or something, we both think it over, when we collect some money we manage to do something, when we have no money we do not do anything but sit and dream" (Family A, Person I, s. 183-184).

Podkreślmy raz jeszcze poznawcze znaczenie takich materiałów. Zapowiedziane już na samym początku jakościowe podejście socjologiczno-antropologiczne, traktowane jako podstawowe narzędzie, znajduje w nich dobitne potwierdzenie. Nadzwyczaj interesująca lektura, której przygotowanie z pewnością wymagało wiele wysiłku.

„Ton” niniejszej wypowiedzi jest, co zapewne łatwo czytelne, bardzo pozytywny. Taki jest też zamiar piszącego te słowa, podkreślającego walory tej pracy, oraz prezentowana konkluzja. Tym niemniej należy też przedstawić kilka uwag o bardziej krytycznej, czy może dyskusyjnej wymowie.

Pierwsza dotyczy poziomu integracji tego tekstu, integracji nieco zachwianej. Od razu dodajmy, że było to raczej nieuniknione. Już to zostało zasygnalizowane, ale powtórnie zaznaczmy, że dzieło traktowane (cytuję z pierwszego zdania 
książki) jako suma wieloletnich studiów musiało zapewne siłą rzeczy stać się wewnętrznie do pewnego stopnia niejednorodne. Akceptuję ten fakt, ale uważam, że z myślą o czytelniku należało pokusić się o mocniejszy komentarz temu poświęcony, o wyraźniejsze, by tak rzec, łączniki między poszczególnymi składnikami.

Druga uwaga jest zapewne bardziej ryzykowna, ale, jeśli mogę powiedzieć w przenośni, rzucam nią pewne wyzwanie autorom i ich oczywistemu przekonaniu o owych trudnych losach, dotkliwych przejawach ubóstwa właśnie na Górnym Śląsku (Śląsku i Zagłębiu). Przecież dowiadujemy się (s. 86) o niezmiennie niższym bezrobociu, a wyższych zarobkach od tych w innych częściach naszego kraju. Jestem najdalszy od kwestionowania tych górnośląskich trudów życia. Czy jednak nie jest tak, że nie wyróżniały się swoją dotkliwością od innych problemowych miejsc, gdzie zachodzące zjawiska i procesy były równie problematyczne, a może jeszcze gorsze od ogólniejszej sytuacji w naszym kraju? Czy nie warto było spojrzeć na nie z bardziej ogólnopolskiej perspektywy?

Trzecia uwaga: in principio w rozmaitych wypowiedziach recenzyjnych nie skupiam się na tym, co nie zostało napisane. Przyjmuję jako oczywiste założenie, że w istocie zawsze dokonujemy selekcji tematycznej, źródłowej, interpretacyjnej. Tym niemniej być może to studium byłoby bardziej komunikatywne, gdybyśmy w trakcie lektury mieli do dyspozycji choćby najbardziej elementarne dane, ukazujące wymiary tego ubóstwa, może stany posiadania czy straty z tym związane. $\mathrm{Z}$ aprobatą powtarzam, że ta praca w swej podstawie, w realizowanym konsekwentnie podejściu jest jakościowo socjologiczno-antropologiczna. Jednakże jedna lub druga liczba dodająca coś do naszej wiedzy o badanych rodzinach nie przekreśliłaby tej strategii. Na przykład: czy i jakie były ich oszczędności, dochody?

\section{Słowo na zakończenie}

Czytając Everyday Hardship i zastanawiając się nad recenzją, sięgnąłem raz jeszcze do ostatniej książki Stanisławy Golinowskiej (2018) — badaczki i autorki szczególnie aktywnej i zasłużonej w zakresie rozpatrywania problematyki biedy w Polsce przez pryzmat makropolityki społecznej. Nie ulega wątpliwości, że zawarty tam obraz metod badawczych oraz, powiedzmy tak, obiektywnie, całościowo ukazywanego zjawiska biedy jest bardzo potrzebny i pożyteczny. Jednocześnie ułatwia zrozumienie, jak znacząca, wyjaśniająca jest linia właściwa recenzowanemu studium.

Jego zasadniczą wyróżniającą się siłą jest ludzki życiowy wymiar tego, co jest nie tylko zbiorem wskaźników, lecz także dotkliwym aspektem realnej ludzkiej egzystencji. Wyjątkowy w swym bogactwie, raz jeszcze godny podkreślenia aneks będący pokłosiem wywiadów bardzo dobrze temu służy. Należy przy tym podkreślić wielość poziomów prezentacji, analizy, interpretacji. Zapoznając się z tą

270 książką, wczytujemy się, by tak rzec, w losy indywidualnych mieszkańców, realia 
życia rodzinnego, funkcjonowanie danych społeczności lokalnych, otrzymując ten złożony obraz. Wreszcie kategoria resilience, czyli aktywna konfrontacja z tymi czasem równie prozaicznymi, co bardzo poważnymi trudnościami, aktualne działania na rzecz ich pokonywania oraz refleksja dotycząca przyszłych możliwości w tym zakresie. Jako punkt wyjścia zostały przyjęte gospodarstwa domowe, ale przez ich pryzmat niejako docieramy do szerszego wachlarza wydarzeń, nawet do swoistej całości Górnego Śląska. Warto przy tym zaznaczyć, że wieloletnie, zaawansowane rozpoznawanie regionalnych górnośląskich zjawisk, procesów, problemów, wielostrukturalnych sposobów ich przezwyciężania wyróżnia się w skali ogólnopolskiej. Można wyrazić zadowolenie, że tak się do tej pory działo i, jak się okazuje, nadal dzieje.

I jeszcze jeden przypis. Gdy mówimy o zrozumieniu i ewentualnym przezwyciężaniu danych problemów, jest m.in. takie popularne i zapewne niewymagające objaśnienia powiedzenie: It takes a village. Praca, którą z przekonaniem, w pochwalnym duchu rekomenduję, dobrze temu służy.

\section{Bibliografia}

Boryczko M., Frysztacki K., Kotlarska-Michalska A., Mendel M., 2016: Solidarnie przeciw biedzie. Socjologiczno-pedagogiczny przyczynek do nowych rozwiazań starego problemu. Gdańsk: Europejskie Centrum Solidarności.

Ehrenreich B., 2001-2011: Nickel and Dimed: On (Not) Getting By in America. New York, NY: Henry Holt and Company, Picador.

Golinowska S., 2018: O polskiej biedzie w latach 1990-2015. Definicje, miary i wyniki. Warszawa: Wydawnictwo Naukowe Scholar.

Grotowska-Leder J., 2002: Fenomen wielkomiejskiej biedy. Od epizodu do underclass. Łódź: Wydawnictwo Uniwersytetu Łódzkiego.

Harrington M., 1962 - 1997: The Other America: Poverty in the United States. New York, NY: Simon \& Schuster, A Touchstone Book.

Hatcher D.L., 2016: The Poverty Industry: The Exploitation of America's Most Vulnerable Citizens. New York, NY: New York University Press.

Tarkowska E., Warzywoda-Kruszyńska W., Wódz K., red., 2003. Biedni o sobie i swoim życiu. Katowice: Wydawnictwo „Śląsk”.

Warzywoda-Kruszyńska W., red. 1998: Żyć i pracować w enklawach biedy. (Klimaty łódzkie). Łódź: Instytut Socjologii Uniwersytetu Łódzkiego.

Will G.F., 2019: The Conservative Sensibility. New York, NY: Hachette Books. 